\title{
Introduction of large-scale biofuel production in a district heating system - an opportunity for reduction of global greenhouse gas emissions
}

\author{
Danica Djuric Ilic, Erik Dotzauer, Louise Trygg and Göran Broman
}

\section{Linköping University Post Print}

\section{Tweet}

N.B.: When citing this work, cite the original article.

Original Publication:

Danica Djuric Ilic, Erik Dotzauer, Louise Trygg and Göran Broman, Introduction of largescale biofuel production in a district heating system - an opportunity for reduction of global greenhouse gas emissions, 2014, Journal of Cleaner Production, (64), 552-561.

http://dx.doi.org/10.1016/j.jclepro.2013.08.029

Copyright: Elsevier http://www.elsevier.com/

Postprint available at: Linköping University Electronic Press http://urn.kb.se/resolve?urn=urn:nbn:se:liu:diva-103643 


\section{Introduction of large-scale biofuel production in a district heating}

\section{system - an opportunity for reduction of global greenhouse gas emissions}

Danica Djuric Ilic ${ }^{\text {a }}{ }^{*}$, Erik Dotzauer ${ }^{\mathrm{b}}$, Louise Trygg ${ }^{\mathrm{a}}$, Göran Broman ${ }^{\mathrm{c}}$

a Division of Energy Systems, Department of Management and Engineering, Linköping University, SE-58183 Linköping, Sweden

${ }^{b}$ School of Sustainable Development of Society and Technology, Mälardalen University, SE-721 23 Västerås, Sweden

${ }^{c}$ Department of Strategic Sustainable Development, School of Engineering, Blekinge Institute of Technology, Karlskrona, Sweden

\section{ABSTRACT}

In this study, cooperation between Stockholm's transport and district heating sectors is analysed. The cooperation concerns the integration of biofuel polygeneration production. A MODEST optimisation model framework is used, assuming various energy market and transport sector scenarios for the year 2030. The scenarios with biofuel production and increased biofuel use in the region are compared with reference scenarios where all new plants introduced into the district heating sector are combined heat and power plants, and the share of biofuel used in the transport sector is the same as today. The results show that the cooperation implies an opportunity to reduce fossil fuel consumption in the

\footnotetext{
${ }^{*}$ Corresponding author. Tel. +46-13-281114; E-mail: danica.djuric.ilic@liu.se (D. Djuric Ilic)
} 
sectors by between $20 \%$ and $65 \%$, depending on energy market conditions and assumed transport sector scenarios. If we consider biomass an unlimited resource, the potential for greenhouse gas emissions reduction is significant. However, considering that biomass is a limited resource, the increase of biomass use in the district heating system may lead to a decrease of biomass use in other energy systems. The potential for reduction of global greenhouse gas emissions is thus highly dependent on the alternative use of biomass. If this alternative is used for co-firing in coal condensing power plants, biomass use in combined heat and power plants would be more desirable than biofuel production through polygeneration. On the other hand, if this alternative is used for traditional biofuel production (without co-production of heat and electricity), the benefits of biofuel production through polygeneration from a greenhouse gas emissions perspective is superior. However, if carbon capture and storage technology is applied on the biofuel polygeneration plants, the introduction of large-scale biofuel production into the district heating system would result in a reduction of global greenhouse gas emissions independent of the assumed alternative use of biomass.

\section{Abbreviations}

$\mathrm{DH}$, district heating; TS, transport sector; DHS, district heating system; GHG, greenhouse gas; FT, Fischer-Tropsch; DME, dimethyl ether; SSF, simultaneous saccharification and fermentation; CHP, combined heat and power; PHEV, Plug-in Hybrid Electric Vehicles; E10, $90 \%$ gasoline mixed with $10 \%$ ethanol; MODEST, Model for Optimisation of Dynamic Energy Systems with Time-dependent components 
and boundary conditions; EMS, energy market scenario; $\mathrm{CO}_{2}$, carbon dioxide; gGHGes, global GHG emissions of the studied system; CCS, carbon capture and storage.

\section{Keywords}

District heating; Biofuel; Energy cooperation; Transport sector; Greenhouse gas emissions

\section{Introduction}

Cooperation between district heating (DH) providers and industry has been of great interest during the last decade. Production of industrial process steam in local DH systems (DHS), utilisation of industrial waste heat in DHS, and conversion to DH for industrial processes have been recognised as measures that often result in a reduction of global carbon dioxide $\left(\mathrm{CO}_{2}\right)$ emissions (Difs et al., 2009; Karlsson and Wolf, 2008; Gebremedhin et al., 2003). Technology of biofuel production (in this study the term biofuel is used to denote renewable transport fuels) through polygeneration where heat production is included creates a possibility for cooperation between the $\mathrm{DH}$ and transport sectors (TS). In a previous study, the integration of ethanol and biogas production through polygeneration with Stockholm's DHS was analysed (Djuric Ilic et al., 2012). Energy market prices for the year 2010 were applied and sensitivity analyses on the price of electricity, biomass and biofuel were performed. The results show that the introduction of ethanol and biogas production into Stockholm's DHS would be profitable when the assumed energy market conditions are considered. However, other studies have shown that the introduction of second-generation biofuel production in DHS is not necessarily economically profitable for the DH supplier (Difs et al., 2010; Fahlén and Ahlgren, 
2009). In order to make this strategy economically attractive for DH producers some policy measures may be needed. The factors that may have major effects on the biofuel production cost are biomass availability and the demand for co-produced heat. This makes forest-rich countries where DHSs are well developed especially interesting for large-scale biofuel production (Wetterlund et al., 2012; Wetterlund, 2010).

The aim of the study is to show how integration of large-scale biofuel production into Stockholm's DHS would affect global greenhouse gas (GHG) emissions and the region's dependency on gasoline and fossil diesel imports. The study has been conducted considering various energy market conditions for the year 2030. An important assumption in the study is that all biofuel used in Stockholm's TS would be produced in the region.

\section{Biofuel production through polygeneration}

The impact of biofuel production and use on global GHG emissions depends on a variety of factors, including the feedstock, process technology, plant capacity and structure of the production system (Porzio et al., 2012; Moriizumi et al., 2012). Three different types of biofuel production plants have been considered in this study. In all plants lingocellulosic biomass is used as feedstock. Two types of plants (Fischer-Tropsch [FT] diesel plant and dimethyl ether [DME] plant) include the thermo-chemical gasification process. The third type is a polygeneration plant where ethanol is produced by a simultaneous saccharification and fermentation (SSF) process.

The first step in the biofuel production process from lingocellulosic biomass is pretreatment, which is performed by chipping or drying. If DME or FT diesel is to be 
produced, the pre-treatment must be followed by thermo-chemical gasification. During the gasification process the biomass is converted into synthesis gas (syngas). After this the $\mathrm{H}_{2} / \mathrm{CO}$ ratio is adjusted and the syngas is purified and upgraded to biofuel. The required $\mathrm{H}_{2} / \mathrm{CO}$ ratio depends on the type of biofuel to be produced. Both the DME production process and FT diesel production process are exothermic, which opens up possibilities for using the excess heat for DH or for combined heat and power (CHP) production (Balat et al., 2009; Wang et al., 2008; Zhang, 2010).

If ethanol is to be produced, the pre-treated slurry is flash-cooled by pressure reduction. Ammonia is added in order to neutralise $\mathrm{pH}$ and the slurry is diluted with fresh water to $10 \%$ water-insoluble solids. In the liquid fraction of the slurry the yeast is cultivated and then supplemented with molasses. SSF is performed at $37{ }^{\circ} \mathrm{C}$ with enzymes and yeast (Barta et al., 2010a; Sassner et al., 2008). The configuration of the process after SSF depends on the various combinations of the desired by-products. The excess solid residue from the distillation and pre-treatment can be treated by anaerobic digestion in order to produce biogas. The raw biogas can be upgraded and used as transportation fuel or used directly as a fuel for CHP production. The residue from anaerobic digestion can also be used for production of steam that can partly be used for the process and partly for CHP production (Barta et al., 2010b).

\section{Case study - Assumptions regarding Stockholm's DHS and TS for the year 2030}

The Stockholm region, with almost two million inhabitants, is the largest metropolitan area in Scandinavia. Together with the surrounding communities the city covers about $6,500 \mathrm{~km}^{2}$. 
The DHS in the county of Stockholm is well developed and delivers more than $12 \mathrm{TWh}$ of heat annually. The system consists of three large DH networks with about 70 heating plants. Six of the plants are CHP plants that produce more than $2 \mathrm{TWh}$ of electricity annually. Two of these CHP plants have installed electricity capacities of $200 \mathrm{MW}$ and $145 \mathrm{MW}$, and are fuelled by oil and coal. The other four CHP plants are fuelled by solid biomass and waste (Dahlroth, 2009; Dotzauer, 2003). By the year 2030 the DHS will be changed. Based on a preliminary study conducted by the DH producers, DH demand should decrease by about $10 \%$. Household waste in the region is also expected to increase by up to 5 TWh (Byman, 2009), and based on that prediction there are plans to introduce two new waste-fired plants in the DHS (Table 1). The CHP plants fuelled by fossil fuels will probably be phased out, as well as one of the biomass-fired CHP plants, which is today almost 50 years old. After those changes the total installed heat capacity of the DHS would be $650 \mathrm{MW}$ lower than the current heat capacity, which means that new plants will need to be built.

About $25 \%$ of the total energy used in Stockholm is used in the TS. The public TS is well developed and the process of introducing "clean" vehicles and alternative fuels in the TS started almost two decades ago. About $37 \%$ of the public busses are run on biofuel (RME, biogas and ethanol). The annual electricity used for the underground and local railway is about $440 \mathrm{GWh}$, and for commuter trains about $160 \mathrm{GWh}$ (SL, 2011). According to Casemyr et al. (2010), by the year 2030 this electricity use will increase up to $980 \mathrm{GWh}$. It is also expected that the number of vehicles in the region will increase (Table 2). An increasing percentage of cars are running on biofuels, but poor biofuel 
supply is the factor that has been recognised as a threat to further development (Hjalmarsson et al., 2011).

A general assumption taken in this study is that in the future gasoline will be sold only as E10, i.e., gasoline that includes approximately $10 \%$ ethanol. It is also assumed that the technology of vehicles will be improved. The average hybrid car will run about $50 \%$ on electricity and the average hybrid bus will run on about $30 \%$ electricity. The future fuel economies are presented in Table 3.

\section{Methodology}

The methodology used in this study includes literature review, data collection and optimisation of the system using a MODEST (Model for Optimisation of Dynamic Energy Systems with Time-dependent components and boundary conditions) framework. MODEST is based on linear programming. Its primary use is for analysis of DHS but MODEST can also be applied to other kinds of energy systems. Input data that needs to be defined before building the model include: time division, discount rate and load demands. The system is represented by a group of different types of nodes. The plants are described in terms of efficiencies, maximum capacity, power-to-heat ratio, maintenance periods and costs, technical lifetime, economic lifetime and investment costs. The optimisation is performed by choosing the optimal operation from existing and potential new plants. The objective is to minimise the annual system cost while satisfying a given load demand during the analysed period. The system costs include: operation and maintenance costs, fuel costs including taxes and fees, new investments, the value of all 
new plants at the end of the analysed period and revenues from by-products (Henning, 1999; Gebremedhin, 2003).

\subsection{Building a model - data and assumptions}

The studied system consists of two sub-systems, the TS and DHS, connected to form an integrated whole. A model of the system is built considering the input data and assumptions presented in section 3 and in this section.

A model of Stockholm's DHS has been built according to the data from Dahlroth (2009) and the future changes to the system mentioned in section 3 . The capital costs in the model are based on a discount rate of $6 \%$. The time frame analysed is 10 years (from 2030 to 2040). Each year is divided into 88 periods. For each of the months from April to October, four time periods are modelled: weekdays, weeknights, and weekend days and nights. For the rest of the year the months are divided into 12 periods and sometimes modelled hour by hour (see Henning 1999 for further explanation). The DH demands for the networks have been calculated based on DH production during the year 2007 and the assumption that DH demand would decrease by $10 \%$ by the year 2030 (see section 3). The curves of the demand have been adjusted to the time division, and the model has also been calibrated against real production data. In order to avoid the differences in base production, all networks in the model have been connected. Despite the decreased DH demand and introduction of the new waste-fired CHP plants, more new plants need to be built by the year 2030. To make the scenarios in the study comparable to each other, the new plants introduced in the DHS have a total heat capacity of $600 \mathrm{MW}$. Five different types of plants have been considered (Table 4). All of the suggested plants are fuelled by 
biomass. Thus, in order to facilitate efficient transportation of the biomass, suitable locations for the new plants are near shipping ports and DH networks. This limits the number of new plants that can be introduced in the DHS to five. In the scenarios with large-scale biofuel production the types and capacities of the new plants have been decided and calculated based on the biofuel demand in the TS. The biofuel demand in the TS has been calculated based on assumptions for the year 2030 regarding the number of vehicles (Table 2), the average annual distance (Table 2), future fuel economy (Table 3) and three future scenarios (described in section 4.5). Investments for the new biofuel plants $\left(\right.$ Cost $\left._{\mathrm{a}}\right)$ have been calculated according to equation (1) where Cost $\mathrm{b}_{\mathrm{b}}$ represents the cost of the base plants (Table 4).

$$
\frac{\text { Cost }_{a}}{\text { Cost }_{b}}=\left(\frac{\text { Capacity }_{a}}{\text { Capacity }_{b}}\right)^{R}
$$

An overall scaling factor (R) of 0.7 (Remer and Chai, 1990) is used for all biofuel plants.

\subsection{Energy market scenarios}

In the present study, different energy market scenarios (EMSs) for Sweden for the year 2030 have been assumed (Table 5).

Four scenarios (EMS 1-4) were developed by Axelsson et al. (2009; Axelsson and Harvey, 2010) using the ENPAC price-setting tool. These scenarios are based on a number of assumptions, such as global energy market scenarios (world market future fossil fuel prices), costs associated with policy instruments, technologies and costs associated with electricity production. The four global energy market scenarios are 
achieved by combining two levels of $\mathrm{CO}_{2}$ emissions charge and two levels of fossil fuel prices (Axelsson and Harvey, 2010). The calculated electricity prices are assumed to be constant during the year and the biomass prices have been calculated considering future users' willingness to pay for it (Axelsson et al., 2009; Axelsson and Harvey, 2010).

The EMS 5 has been developed by Jeffries et al. (2011). In this scenario about $50 \%$ of the electricity will be produced by renewable energy sources, though marginal production of electricity will still be produced by fossil fuels. In this EMS, the prices have not been calculated as interdependent parameters. The electricity and fossil fuel prices have been derived from the prices for the year 2010 and forecasted using different growth rates that are based on a number of assumptions. The future biomass prices have been determined by applying a demand-driven approach and assuming that increased biomass demand will lead to an increased biomass price. The process for creating the scenario is explained in more detail by Jeffries et al. (2011).

In all scenarios it is assumed that the waste fuel will not be subject to any purchasing costs or taxes.

Policy instruments included in this study are: $\mathrm{CO}_{2}$ emissions charges and premiums paid to producers of renewable electricity (Table 5). The premium paid is based on the electricity certificate system that went into effect in Sweden in May 2003 (SEA, 2010). For each MWh of renewable electricity produced the producers receive one electricity certificate. By selling the electricity certificate to electricity distributors the producers get extra revenue. In order to guarantee the extra revenue, some of the users are required to 
buy a certain share (RES-E quota) of the electricity used at the higher price (SEA, 2010).

The assumed RES-E quotas are presented in Table 5.

Further introduction of biofuel in the TS depends on the user's willingness to pay for it. In order to increase the share of biofuel use in the TS, the final biofuel prices at filling stations should thus not be higher than the price of the fossil fuel replaced. Biogas and ethanol are considered replacements for gasoline while FT diesel and DME are assumed to be replacements for fossil diesel. The revenues that the producers would get for the biofuel produced are estimated considering the cost for the transportation of the biofuel to the filling stations (Table 5). In the present study it is assumed that the average distance from the production plants to the filling stations would be about $50 \mathrm{~km}$ for ethanol, FT diesel and DME. For biogas it is assumed that the filling points would be in the vicinity of the plants.

\subsection{Estimating the effects on the global GHG emissions}

A number of studies show the importance of applying a system approach and life-cycle assessment when estimating the impact of biofuel production and use on global GHG emissions (Melamu and von Blottnitz, 2011; Khatiwada and Silveira, 2011; Sandén and Karlström, 2007). Thus, the global GHG emissions of the studied system (gGHGes) have been analysed, considering not only the emissions during the combustion process, but also the emissions during the whole life cycle of the fuels (Figure 1; Table 6). Besides $\mathrm{CO}_{2}$, two more greenhouse gases have been considered: methane $\left(\mathrm{CH}_{4}\right)$ and nitrous oxide $\left(\mathrm{N}_{2} \mathrm{O}\right)$. The values of the $\mathrm{GHG}$ emissions are presented as $\mathrm{CO}_{2}$ equivalent $\left(\mathrm{CO}_{2} \mathrm{eq}\right)$ emissions. The $\mathrm{CH}_{4}$ and $\mathrm{N}_{2} \mathrm{O}$ emissions have been included using the conversion 
coefficients 25 and 298, respectively. Data for GHG emissions during waste and biomass transportation are calculated based on the research presented in Börjesson and Gustavsson (1996). It is assumed that the waste is transported by truck with an average distance of $60 \mathrm{~km}$. The GHG emissions from the waste landfills have not been considered in the present study. In the reference scenario it is assumed that $60 \%$ of the biomass used is transported from the Baltic countries. For the scenarios with large-scale biofuel production it is assumed that $75 \%$ is transported from the Baltic region. It is also assumed that the imported biomass is transported approximately $400 \mathrm{~km}$ by truck and approximately $400 \mathrm{~km}$ by boat. In all scenarios the rest of the biomass is transported from the north of Sweden by train at an average distance of about $400 \mathrm{~km}$. Data for wellto-tank GHG emissions for imported gasoline, diesel and biofuels have been found in Börjesson et al. (2010). Börjesson et al. (2010) applied a life cycle assessment methodology which includes the by-products' indirect effect on GHG emissions. This can lead to a negative well-to-tank GHG emissions factor in some cases. In the reference scenarios ethanol used in the region is imported from Brazil where it is produced from sugar cane. The biogas used in the region is produced from three different feedstocks: household waste, industry and manure. In the scenarios with large-scale biofuel production in the DHS, the GHG emissions during the transportation of the biofuel produced to the filling stations are based on Wetterlund (2010). The assumed average distance between the production plants and filling stations is $50 \mathrm{~km}$ (see section 4.2). The well-to-gate and combustion GHG emissions factors for the fossil oil have been found in Edwards (2011). 
Effects on the power sector caused by electricity production in the DHS are calculated considering the "build" margin power technology. The "build" margin power plants are plants that would not be built in the future, if new CHP or polygeneration plants with electricity production included were introduced into the DHS. Axelsson and Harvey (2010) identified two different possible build margins for the year 2030: coal power plants and coal power plants with carbon capture and storage (CCS). CCS is assumed to be an economically attractive technology in EMSs where the $\mathrm{CO}_{2}$ charge has a high level (EMS 2 and EMS 4). The build margins assumed for EMS 5 are natural gas combined cycle (NGCC) power plants.

Three analyses have been performed, based on three different assumptions considering future biomass availability and future alternative use of biomass. In the first analysis it is assumed that biomass is an unlimited resource. Since biomass combustion can be considered carbon neutral (IPCC, 2001), only GHG emissions from the transportation of biomass are considered (Table 6). However, since biomass will probably become a subject of competition in the future, increased biomass use in the DHS would lead to decreased use in another energy system. Thus, a more comprehensive system approach has been taken in the second and third analysis. In the second analysis, it has been assumed that increased biomass use in the DHS will lead to decreased biomass co-firing in coal condensing power plants, and consequently there will be increased GHG emissions in the electricity sector (Table 6). In the third analysis, production of biofuel has been considered the alternative for biomass use. In this case the increased biomass use in the DHS would lead to decreased biomass use for traditional biofuel production 
that does not include co-production of heat and electricity. This will result in increased GHG emissions in the TS (Table 6) (Axelsson and Harvey, 2010).

\subsection{Evaluation of CCS potential - approach and assumptions}

In three of the EMSs considered in the study (EMS 2, EMS 4 and EMS 5), it is assumed that the CCS technology is commercially available. Thus, for those EMSs more analyses have been done assuming that CCS will be applied to new plants introduced into the DHS. In the CHP production, total biomass combustion is assumed. In biofuel production, the biomass will only be partly combusted since a certain amount of carbon will still be present in the biofuel produced. $\mathrm{CO}_{2}$ emissions per $1 \mathrm{MWh}$ of biomass during the biofuel production process ( $e_{\text {proc. }}$ ) have been calculated according to equation (2)

$e_{\text {proc.c. }}=e_{\text {t.c.biomass }}-\sum_{i=1}^{n}\left(E f f \cdot e_{\text {t.c.biofuel }}\right)$

where $e_{\text {t.c.biomass }}$ represents the $\mathrm{CO}_{2}$ emission factors during the total combustion of the biomass (Table 7); $n$ is the number of biofuels produced in the plant; Eff ${ }_{i}$ is the biofuel production efficiency (Table 4); $e_{\text {t.c.biofuel }}$ represents the $\mathrm{CO}_{2}$ emission factors from the total combustion of the biofuel (Table 7).

Based on a research study (e.g. Damen et al., 2009; Möllersten et al., 2003) it has been assumed that the $\mathrm{CO}_{2}$ capture efficiency is about $90 \%$ in all new plants and that the electricity requirement for $\mathrm{CO}_{2}$ capture and compression to 110 bar is about $0.14 \mathrm{kWh} / \mathrm{kgCO}_{2}$.

The economic evaluation of the introduction of CCS is not included in this study. 


\subsection{Description of the chosen scenarios}

A number of different scenarios have been analysed considering the assumed EMS (Table 5) and different future TS scenarios (Figure 2).

Two different reference scenarios for TS have been assumed. In the first reference scenario (r1-4), which concerns EMS 1-4, the share of the fuel used for different types of vehicles is the same as today (SL, 2011; SIKA, 2011). The second reference scenario is based on the research presented in Jeffries et al. (2011) and concerns EMS 5. In this scenario, a strong electrification of road transport is assumed, and the share of biofuel used in TS is about $35 \%$. In both scenarios biofuel is imported from other regions; only about $0.1 \mathrm{TWh}$ of biogas is produced in one of the DH plants. The new plants introduced into the DHS are CHP plants with a total heat capacity of $600 \mathrm{MW}$ (see section 4.1).

Three future scenarios have been developed to illustrate possible pathways to lower the share of fossil fuels in the TS. The "biogas" and "electricity" scenarios are based on two different local policy strategies discussed in Hjalmarsson (2011). The "diesel" scenario is based on the current trend of switching from gasoline to diesel fuel (Energimyndigheten, 2011). The types of plants that need to be introduced into the DHS depend on the biofuel demand in the TS. In order to increase the total heat capacity of the system by $600 \mathrm{MW}$, new CHP plants are introduced in the DHS in all scenarios.

The electricity demand for the underground and local railways as well as for commuter trains, about $980 \mathrm{GWh}$ (see section 3), is taken into account in all scenarios. 


\section{Results and discussion}

The type and capacity of the new plants that need to be introduced into the DHS have been estimated according to the biofuel demand. The total investment costs for different scenarios (Table 8) vary within a range of $€ 670 \times 10^{6}$ (the reference scenario) and $€ 1678 \times 10^{6}$ (the "diesel" scenario). In all scenarios new CHP plants should be introduced into the DHS (Table 8) in order to satisfy the need to increase total heat capacity by $600 \mathrm{MW}$.

\subsection{Effects on energy supply security}

Compared to the reference scenarios the fuel mix in the scenarios with established cooperation between the DHS and TS is changed. The total energy use in the system is slightly lower than in the reference scenarios, but biomass use increases (Figure 3). In most of the scenarios with large-scale biofuel production, the total biomass consumption is about $4 \mathrm{TWh}$ higher than in the reference scenarios. The share of biomass used is higher than $50 \%$, which makes the system more sensitive to biomass price and availability. The highest increase is found in the biogas scenarios (b1-5), but it is also followed by the highest biofuel production.

In almost all scenarios the electricity production is higher than $2.5 \mathrm{TWh}$. However, the electricity production in the scenarios with large-scale biofuel production is somewhat lower than in the reference scenarios. The variations in the electricity used depend on the ratio between the electricity price and biomass price, and on the electricity used in the TS. A higher ratio implies less use of electricity in the DHS. The scenario with the 
highest electricity use is reference scenario $\mathrm{r} 5$, where a strong electrification in the TS is assumed (see section 4.5).

In all scenarios with large-scale biofuel production, fossil fuel accounts for about $15 \%$ of total energy use (Figure 3). Fossil fuel use is about 3 TWh annually, or even less. For EMSs where the reference scenario in the TS is characterised by a high share of fossil fuel used (EMS 1-4), the cooperation results in an approximately $65 \%$ reduction in fossil fuel consumption in the "biogas" and "electricity" scenarios, and approximately $50 \%$ reduction in the "diesel" scenario (Figure 3). When the reference scenario is characterised by a high share of electricity used in the TS (EMS 5), the reduction in fossil fuel consumption ranges between $20 \%$ and $45 \%$ (Figure 3 ).

By reducing dependency on gasoline and fossil diesel imports, the cooperation between the DHS and TS can contribute to sustainable development in the region. Moreover, a secure biofuel supply infrastructure can be developed. The amount of gasoline, diesel and ethanol imported to the region would decrease from about $0.6 \times 10^{6} \mathrm{t}$ to $0.2 \times 10^{6} \mathrm{t}$ annually (Figure 3). On the other hand, since in the scenarios with large-scale biofuel production about $3 \times 10^{6} \mathrm{t}$ of biomass is used (which is about $50 \%$ higher than the biomass amount used in the reference scenarios), the transportation infrastructure for biomass should probably be changed.

\subsection{Effects on the gGHGes (DHS + TS)}

Figure 4 shows how the gGHGes (see section 4.3) are changed if DH producers invest in biofuel production instead of in CHP. 
If biomass is considered an unlimited resource, the introduction of large-scale biofuel production into the DHS results in a considerable reduction in GHG emissions. In most of the scenarios the gGHGes is between $35 \%$ and $55 \%$ lower if the DH producers invest in biofuel production instead of in CHP production (Figure 4). The greatest benefits are achieved for the "biogas" scenarios. In this case, the gGHGes are between $45 \%$ and $57 \%$ lower compared to the reference scenarios. However, the "biogas" scenarios are not necessarily the best options if the alternative use of biomass is considered. This is due to the fact that biomass used in the "biogas" scenario is higher compared to the other scenarios with large-scale biofuel production (Figure 3). This implies that the GHG emissions, due to decreased use of biomass in some other energy systems, are more noticeable.

If the alternative use is traditional biofuel production which does not include co-production of heat and electricity, the large-scale biofuel production still has potential to contribute to the reduction of global GHG emissions. However, the potential is significantly lower. The gGHGes are between $12 \%$ and $18 \%$ lower compared to the corresponding reference scenarios (Figure 4). The only exceptions are the scenarios with higher electricity use in the TS, when the marginal electricity is produced in coal condensing power plants.

The influence of marginal electricity production is most noticeable in the "electricity" scenarios. An increased use of electricity in the TS is proven to be a poor strategy for GHG emission mitigation as long as the production of marginal electricity results in high GHG emissions (EMS 1 and EMS 3). The significant increase of electricity use in the TS 
when the marginal electricity is produced in coal condensing power plants ("electricity" scenario - EMS 1 and EMS 3) is proven to be the worst strategy suggested in the study.

If coal condensing power plants are assumed to be the alternative users of biomass (see section 4.3), the large-scale biofuel production introduced into the DHS would not signify a potential for reduction of GHG emissions. The increased biomass use in the DHS (Figure 3) then leads to an increased use of coal in the power sector and consequently leads to increased GHG emissions. The consequences are especially notable in EMS 1 and EMS 3. In those EMSs the marginal electricity is produced in coal condensing power plants followed by high $\mathrm{CO}_{2}$ eq emissions by MWh produced (see Table 6). Thus, replacing the marginal electricity with the electricity produced in the new CHP plants results in higher benefits from a GHG emissions perspective than from replacing the transport fossil fuels with the biofuel produced. In this case (EMS 1 and EMS 3) the gGHGes are between $10 \%$ and $20 \%$ higher (depending on the TS scenario) if the DH producers invest in biofuel production rather than in CHP production (Figure 4).

\subsection{The CCS potential}

The $\mathrm{CO}_{2}$ capture potentials for the new plants (Table 9) are calculated using equation (2) and assume that the capture efficiency is $90 \%$ (see section 4.4).

The CCS potential differs between the scenarios (Table 10). The CCS potential in the scenarios with large-scale biofuel production varies within a range of $1.78 \times 10^{6} \mathrm{t}$ and $2.34 \times 10^{6} \mathrm{t}$ of $\mathrm{CO}_{2}$. Due to lower biomass use in the new CHP plants (Figure 3) in the reference scenarios, the potential is significantly lower and varies within a range of $1.06 \times 10^{6} \mathrm{t}$ and $1.58 \times 10^{6} \mathrm{t}$. In the scenarios with large-scale biofuel production the 
electricity used in the CCS processes varies between 249 and $328 \mathrm{GWh}$, which is about $11 \%$ of the electricity produced in the system. The electricity used in the CCS processes in the reference scenarios is about $7 \%$ of the electricity produced.

Figure 5 shows relative changes in the gGHGes (see section 4.3) if DH producers invest in biofuel production instead of in CHP. The utilisation of CCS may be a key option to significantly reduce gGHGes (Figure 5). When biomass is an unlimited resource the only GHG emissions associated with biomass use are the emissions from the transportation of biomass (see section 4.3). However, since the $\mathrm{CO}_{2}$ emitted during biomass combustion can be captured at the same time, the gGHGes can be negative. In this case the gGHGes are negative in all scenarios with large-scale biofuel production. CCS potential in the reference scenarios is much lower (Table 10). In those scenarios the gGHGes are positive. Thus, if the biomass is an unlimited resource, the gGHGes is lowered by more than $100 \%$ (between $110 \%$ and $200 \%$; see Figure 5) if the DH producers invest in large-scale biofuel production instead of in CHP.

If the CCS technology is applied the cooperation between the DHS and TS results in a reduction of global GHG emissions even in the scenarios where the alternative use of biomass is in coal-condensing power plants. If the alternative use of biomass is traditional biofuel production, the reductions vary within a range of $45 \%$ and $60 \%$, depending on the scenario.

Challenges facing CCS deployment are very intensive capital investments, additional energy use and increased water consumption. In order to deploy a CCS technology, an infrastructure for $\mathrm{CO}_{2}$ transport needs to be established. Cooleman (2009) and Damen et 
al. (2009) recognise pipelines as the most likely transportation option for the captured $\mathrm{CO}_{2}$ in the future. Another important issue is that there is a potential risk of sudden and gradual $\mathrm{CO}_{2}$ leakage which could endanger people and the climate system. Because of this, in some studies (Sprenga et al., 2007; Patil et al., 2010) the technology has been recognized only as a possibility to exchange one problem for another. The temporary solution offered would have long-term negative consequences.

\section{Conclusion}

The cooperation between Stockholm's district heating system and transport sector, established through large-scale biofuel production in the district heating system, significantly changes the total fuel used in the region. The biomass used in the district heating system increases up to $10 \mathrm{TWh}$ annually. This makes both energy systems highly vulnerable to biomass availability, yet at the same time it leads to a significant increase in renewable energy share in the region.

The main benefit that can be achieved with the cooperation is a reduced dependency on imported fossil fuels. The cooperation enables development of a local biofuel supply chain, which facilitates the introduction of biofuel in the transport sector. Depending on the assumed scenario, the biofuel used in the transport sector ranges between $61 \%$ and $78 \%$ of the total energy used.

When estimating the GHG mitigation potential it is important to apply a systems approach and to include possible consequences that can arise, not only in the analysed system but also in interacting systems. The marginal electricity production as well as the biomass availability and alternative use of biomass have been shown to have a significant 
influence on the GHG mitigation potential. As long as the marginal electricity has a $\mathrm{CO}_{2}$ eq emissions factor higher than transport fossil fuels, the electricity use in the transport sector will lead to an increase of GHG emissions from a global perspective. Thus, since currently less than $20 \%$ of the total electricity consumption in the EU-27 countries is produced by renewable sources (EUROSTAT, 2011), electricity use in the transport sector can be considered a solution only in the distant future. If biomass is an unlimited resource, large-scale biofuel production introduced in the district heating system results in significant reduction of GHG emissions. If the district heating producers invest in biofuel production instead of in CHP, the global GHG emissions of the studied system are between $35 \%$ and $55 \%$ lower in all considered scenarios, except in the scenarios with high electricity use in the transport sector, where the marginal electricity production is linked to high GHG emissions. When biomass is considered to be a limited resource, the benefit from a GHG emissions perspective is not obvious. If the alternative use of biomass is co-firing in coal condensing power plants, investments in CHP production are more desirable than investments in biofuel production through polygeneration. If the alternative use of biomass is traditional biofuel production which does not include co-production of heat and electricity, the global GHG emissions of the studied system are about $10 \%$ lower with large-scale biofuel production, compared to the scenarios with CHP production. This also indicates that polygeneration biofuel production technology is more advantageous compared to traditional biofuel production technology.

Carbon capture and storage may play a decisive role in reaching targets for GHG emissions reduction in the region. However, the utilisation of this technology requires 
development of a large infrastructure for transportation of $\mathrm{CO}_{2}$ from capture locations to storage sites.

The results in this article are based on a case study. However, they can probably be useful for other regions with developed DHS which are located close to heavily forested areas.

\section{Acknowledgements}

This research was conducted under the auspices of the Energy Systems Programme at Linköping University, which is financially supported by the Swedish Energy Agency, and within the project Sustainable Cities in a Backcasting Perspective, which is financially supported by the Swedish District Heating Association, Blekinge Institute of Technology and Linköping University. The financial support is gratefully acknowledged.

\section{References}

Axelsson, E., Harvey, S., Berntsson, T., 2009. A tool for creating energy market scenarios for evaluation of investments in energy intensive industry. Energy 34(12), 2069-2074.

Axelsson, E., Harvey, S., 2010. Scenarios for assessing profitability and carbon balances of energy investments in industry. AGS Pathways report 2010:EU1. The Alliance for Global Sustainability, Göteborg, Sweden.

Balat, M., Balat, M., Kirtay, E., Balat, H., 2009. Main routes for the thermo-conversion of biomass into fuels and chemicals. Part 2: Gasification systems. Energy Convers. Manag. 50(12), 3158-3168. 
Barta, Z., Kovacs, K., Reczey, K., Zacchi, G., 2010a. Process design and economics of on-site cellulase production on various carbon sources in a softwood-based ethanol plant. Enzyme Research. doi:10.4061/2010/734182.

Barta Z., Reczey K., Zacchi G., 2010b. Techno-economic evaluation of stillage treatment with anaerobic digestion in a softwood-to-ethanol process. Biotechnology for Biofuels $3(21), 1-11$.

Byman, K., 2009. Energy future of the county of Stockholm $2010-2050$. The road to a reduced environmental impact. Regionplanekontoret, Stockholm County Council (in Swedish).

Börjesson, P., Gustavsson, L., 1996. Regional production and utilization of biomass in Sweden. Energy 21(9), 747-764.

Börjesson, P., Tufvesson, L., Lantz, M., 2010. Life Cycle Assessment of Biofuels in Sweden. Lund Tekniska Högskola, Lund University, rapport nr 70 (in Swedish).

Casemyr, M., Blomquist, A.,_Olsson, J., 2010. Traffic plans 2020. SL (in Swedish).

Cooleman, D. L., 2009. Transport Infrastructure Rationale for Carbon Dioxide Capture \& Storage in the European Union to 2050. Energy Proced. 1(1), 1673-1681.

Dahlroth, B., 2009. Open district heating network in greater Stockholm. Stockholm, Sweden: Fastighetsägarna Stockholm (in Swedish). 
Damen, K., Faaij, A., Turkenburg W., 2009. Pathways toward large-scale implementation of $\mathrm{CO}_{2}$ capture and storage: A case study for the Netherlands. Greenh. Gas Control 3(2), 217-236.

Djuric Ilic, D., Dotzauer, E., Trygg, L., 2012. District heating and ethanol production through polygeneration in Stockholm. Appl. Energy 91(1), 214-221.

Difs, K., Danestig, M., Trygg, L., 2009. Increased use of district heating in industrial processes - Impact on heat load duration. Appl. Energy 86(11), 2327-2334.

Difs, K., Wetterlund, E., Trygg, L., Söderström, M., 2010. Biomass gasification opportunities in district heating system. Biomass Bioenergy 34(5), 637-651.

Dotzauer, E., 2003. Experiences in mid-term planning of district heating systems. Energy 28(15), 1545-1555.

Edwards, R., Larivé, J-F., Beziat, J.-C., 2011. Well to wheels analysis of future automotive fuels and powertrains in the European context. Well to tank Report Appendix 1, Version 3c. European Commission Joint Research Centre, Institute for Energy; CONCAWE; Renault/EUCAR. (Available on http://iet.jrc.ec.europa.eu/aboutjec; accessed on 10 September 2012)

E.ON, 2011. Energy from waste. E.ON Värme Sverige AB och E.ON Gas Sverige AB (in Swedish).

Energimyndigheten, 2011. Long-term forecast 2010. Report no. ER 2011:03. Energimyndigheten (in Swedish). 
EUROSTAT, European commission, 2011. Energy, transport and environment indicators. Publication office of the European Union, Luxembourg; ISSN 1725-4566.

Fahlén, E., Ahlgren, E.O., 2009. Assessment of integration of different biomass gasification alternatives in a district-heating system. Energy 34(12), 2184-2195.

Gebremedhin, A., 2003. Regional and industrial co-operation in district heating systems (Dissertations No. 849). Linköping (Sweden): Linköping University.

Hansson, H., Larsson, S-E., Nyström, O., Olsson, F., Ridell, B., 2007. Electric power from new plants. Elforsk: Stockholm (in Swedish).

Henning, D., 1999. Optimisation of local and national energy systems. Development and use of the MODEST model (Dissertation No. 559). Linköping (Sweden): Linköping University.

Hjalmarsson, L., Larsson, M., Olsson, L., Wikström, M., 2011. Pathways to a renewable road transport system in Stockholm 2030. IEI Energisystem, arbetsnotat nr. 48, ISSN 1403-8307.

IPCC 2001, 'Climate Change 2001: Synthesis Report', Eds. R T Watson and the Core Writing Team, Contribution of Working Groups I, II, and III to the Third Assessment Report of the International Panel on Climate Changes, University Press, New York, USA.

Jeffries, B., Deng, Y., Cornelissen, S., Klaus S., 2011. The energy report. $100 \%$ renewable energy by 2050. WWF, Gland, Switzerland; Ecofys, RK Utrecht, The Netherlands; OMA, AD Rotterdam, The Netherlands. 
Karlsson, M., Wolf, A., 2008. Using an optimization model to evaluate the economic benefits of industrial symbiosis in the forest industry. J. Clean. Prod. 16(14), 1536-1544.

Khatiwada, D., Silveira, S., 2011. Greenhouse gas balances of molasses based ethanol in Nepal. J. Clean. Prod. 19(13), 1471-1485.

Melamu, R., von Blottnitz, H., 2011. 2nd Generation biofuels a sure bet? A life cycle assessment of how things could go wrong. J. Clean. Prod. 19(2-3), 138-144.

Moriizumi, Y., Suksri, P., Hondo, H., Wake, Y., 2012. Effect of biogas utilization and plant co location on life-cycle greenhouse gas emissions of cassava ethanol production. J. Clean. Prod. 37, 326-334.

Möllersten, K., Yan, J., Moreira, J. R., 2003. Potential market niches for biomass energy with $\mathrm{CO}_{2}$ capture and storage-Opportunities for energy supply with negative $\mathrm{CO}_{2}$ emissions. Biomass Bioenergy 25(3), 273-285.

Patil, R. H., Colls, J. J., Steven, M. D., 2010. Effects of $\mathrm{CO}_{2}$ gas as leaks from geological storage sites on agro-ecosystems. Energy 35(12), 4587-4591.

Porzio, G.F., Prussi, M., Chiaramonti, D., Pari, L., 2012. Modelling lignocellulosic bioethanol from poplar: estimation of the level of process integration, yield and potential for co-products. J. Clean. Prod., doi: 10.1016/j.jclepro.2012.01.028

Remer, D.S., Chai, L.H., 1990. Design cost factors for scaling-up engineering equipment. Chemical Engineering Progress 86(8), 77-82. 
Sandén, B., Karlström, M., 2007. Positive and negative feedback in consequential lifecycle assessment. J. Clean. Prod. 15(15), 1469-1481.

Sassner, P., Galbe, M., Zacchi, G., 2008. Techno-economic evaluation of bioethanol production from three different lignocellulosic materials. Biomass Bioenergy 32(5), 422430.

SEA, 2010. Energy in Sweden 2010. Swedish Energy Agency (SEA), Eskilstuna, Sweden.

SIKA, 2011. Swedish Institute for Transport and Communications Analysis. Fordon 2010 - Vehicle statistics 2010.

SL, 2011. The importance of SL for the county of Stockholm. Intellecta Infolog, Solna (in Swedish).

Sprenga, D., Marlandb, G., Weinberg, A. M., 2007. $\mathrm{CO}_{2}$ capture and storage: Another Faustian Bargain? Energy Policy 35(2), 850-854.

Wang, Y., Fan, W., Liu, Y., Zeng, Z., Hao, X., Chang, M., Zhang, C., Xu, Y., Xiang, H., Li, Y., 2008. Modeling of the Fischer-Tropsch synthesis in slurry bubble column reactors. Chem. Eng. Process 47(2), 222-228.

Wetterlund, E., Leduc, S., Dotzauer, E., Kindermann, G., 2012. Optimal localisation of biofuel production on European scale. Energy 41(1), 462-472.

Wetterlund, E., Pettersson, K., Harvey, S., 2009. Integrating biomass gasification with pulp and paper production - systems analysis of economic performance and $\mathrm{CO}_{2}$ 
emissions. Proceeding Brazil 2009. 22 ${ }^{\text {nd }}$ International Conference on Efficiency, Cost, Optimization Simulation and Environmental Impact of Energy Systems. Paraná, Brazil.

Wetterlund, E., 2010. Optimal localization of biofuel production on a European scale.

International Institute_for Applied Systems Analysis, Laxenburg, Austria, Interim report, IR-10-020.

Zhang, W., 2010. Automotive fuel from biomass via gasification. Fuel Process. Technol. 91(8), 866-876.

\section{Figures}




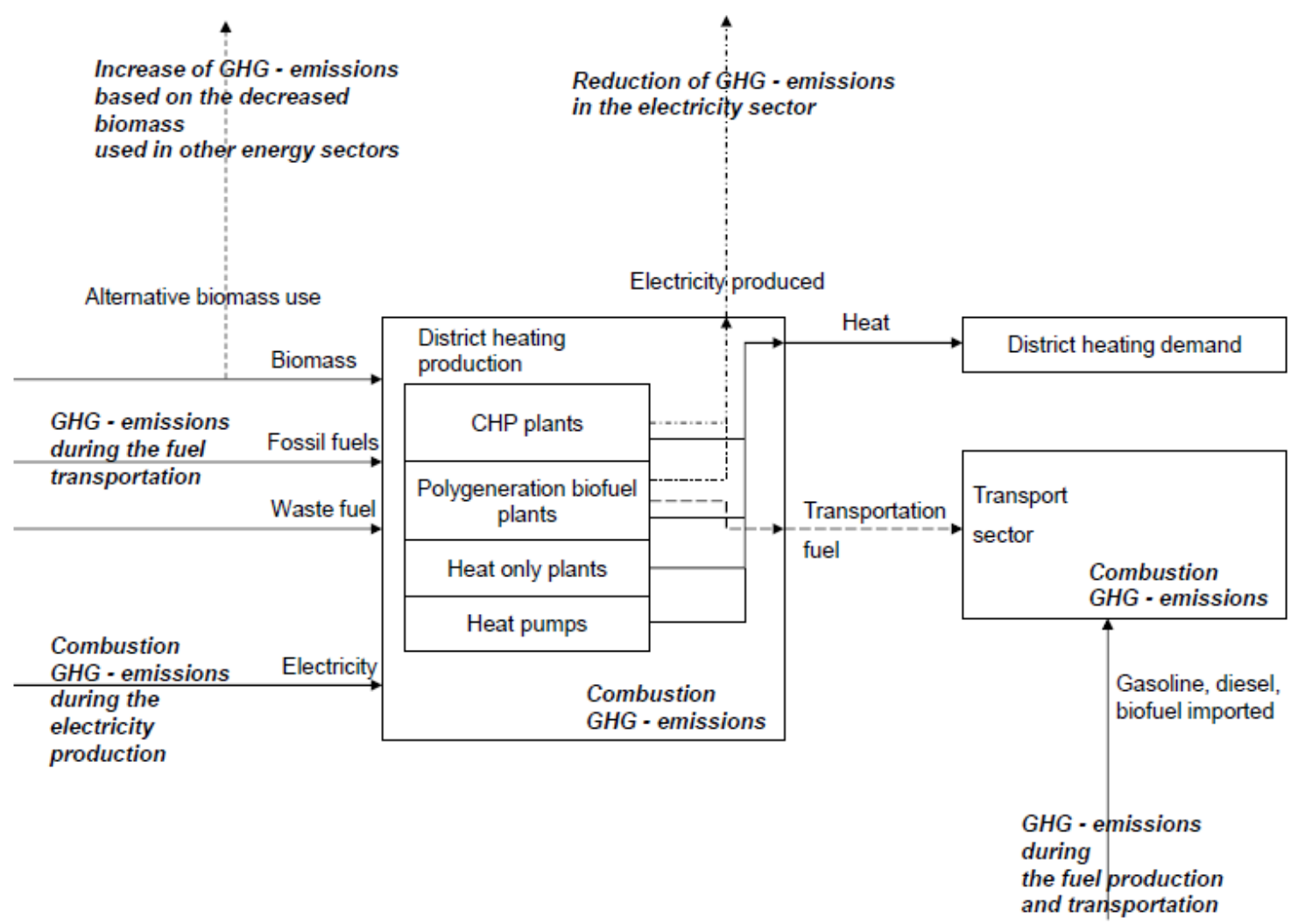

Figure 1 A graphical description of the system approach used for evaluation of the impact on global GHG emissions (global GHG emissions of the studied system gGHGes). 


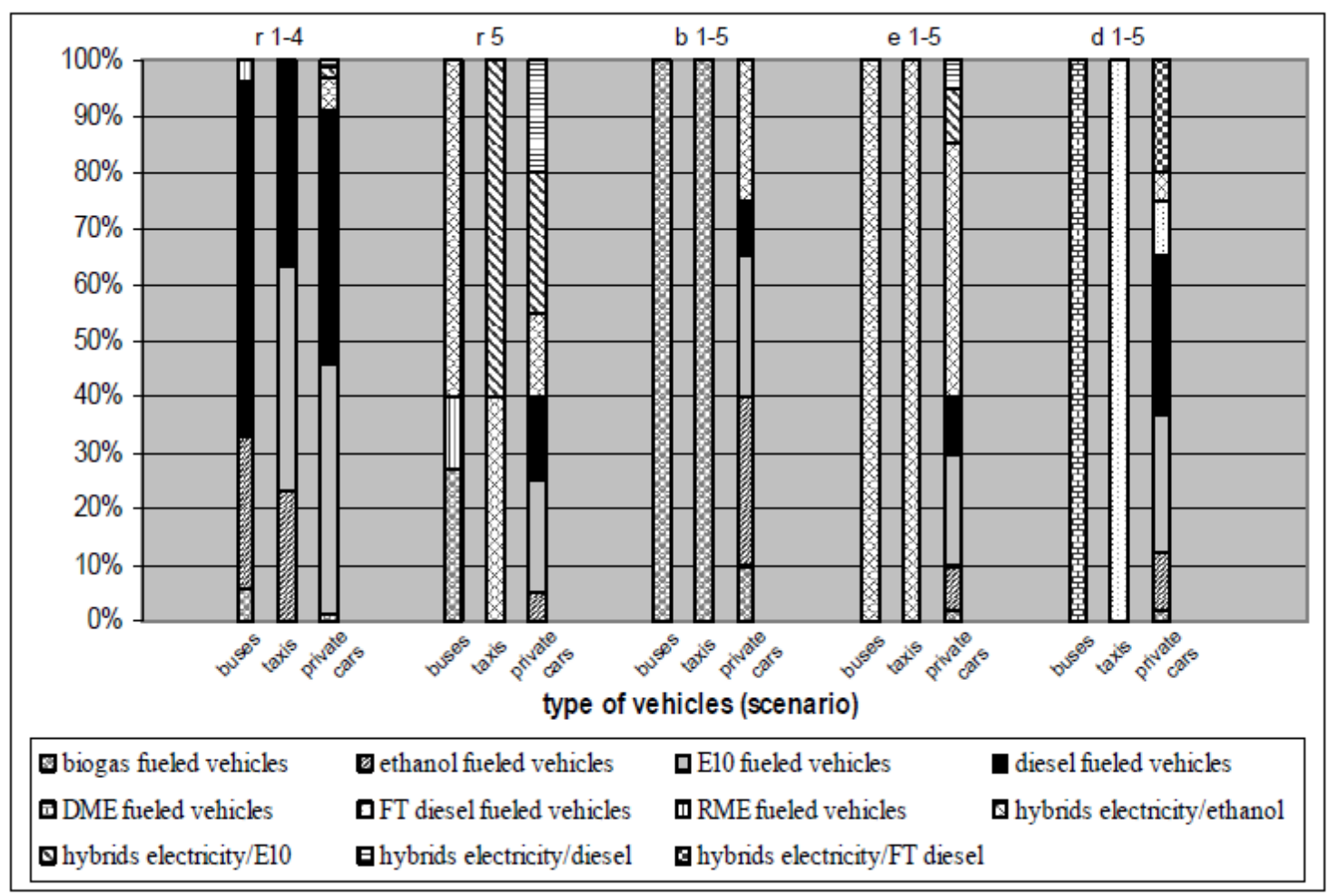

Figure 2 Structure of the vehicle pool in Stockholm's TS - the assumed future scenarios for the year 2030: reference scenarios (r1-5), "biogas" scenarios (b1-5), "electricity" scenarios (e1-5) and "diesel" scenarios (d1-5). 


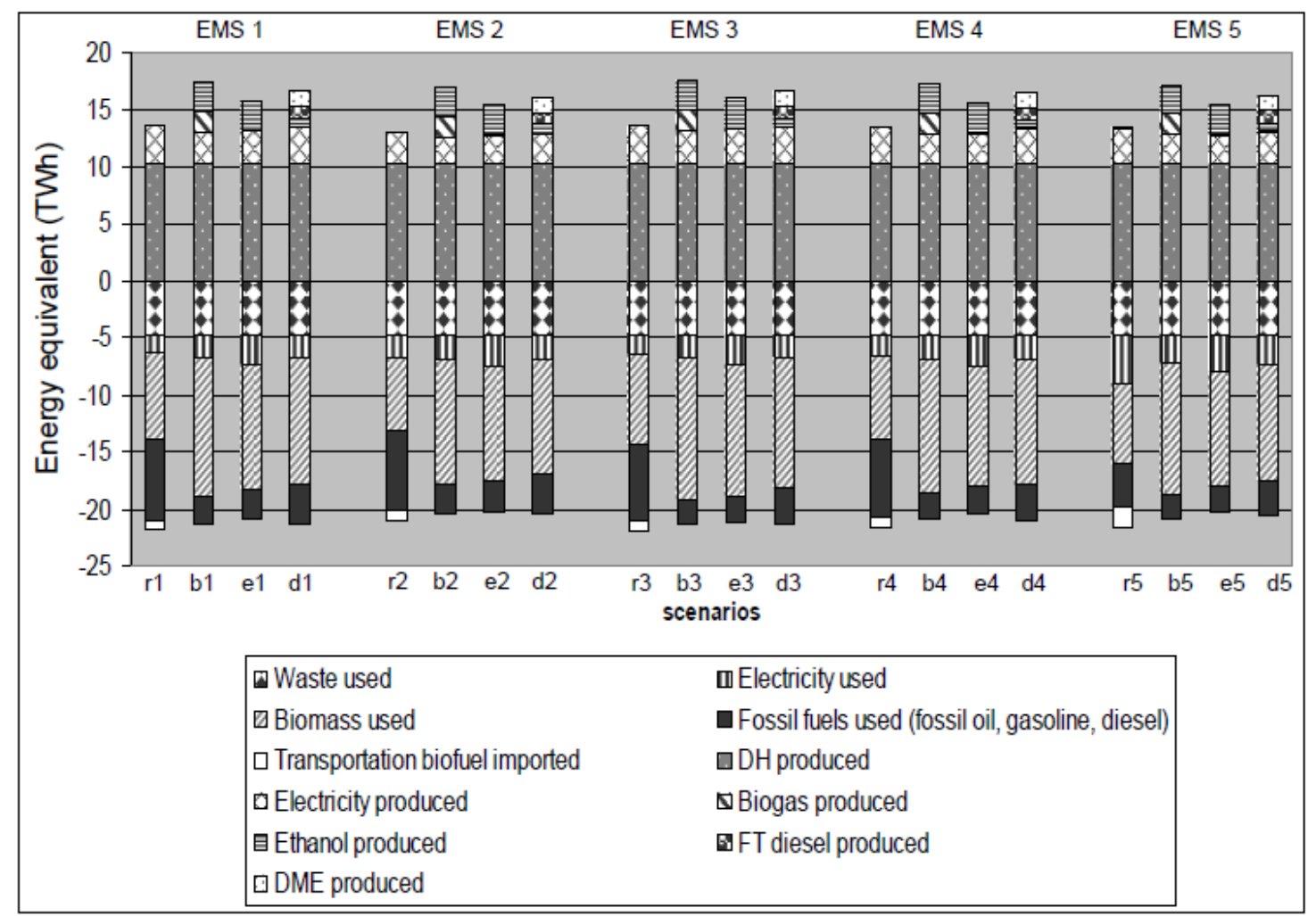

Figure 3 Energy equivalents of the fuel and electricity used (the negative part of the figure) and produced (the positive part of the figure) in the system. 


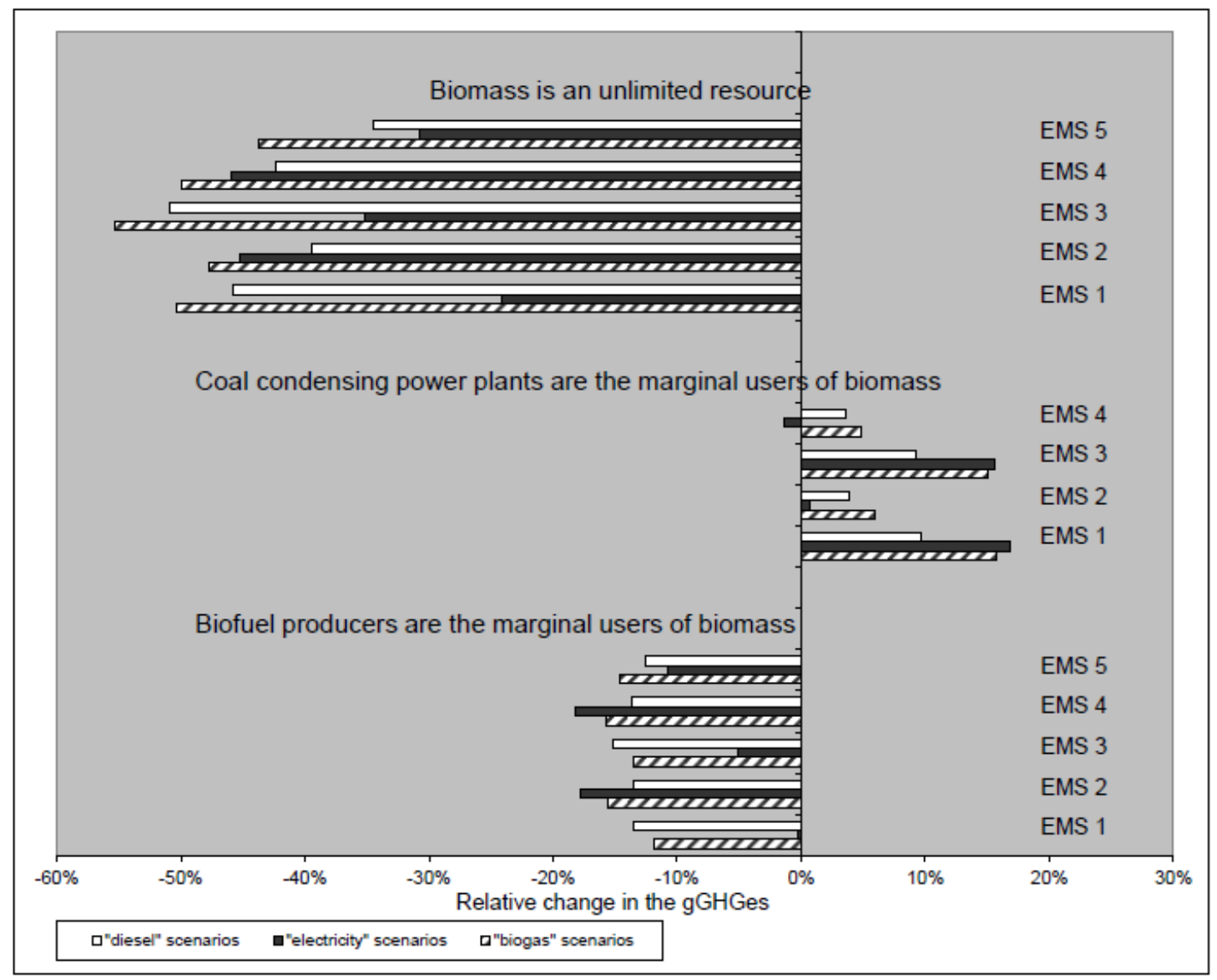

Figure 4 The changes in the gGHGes if the DH producers were to invest in biofuel production rather than CHP production. 


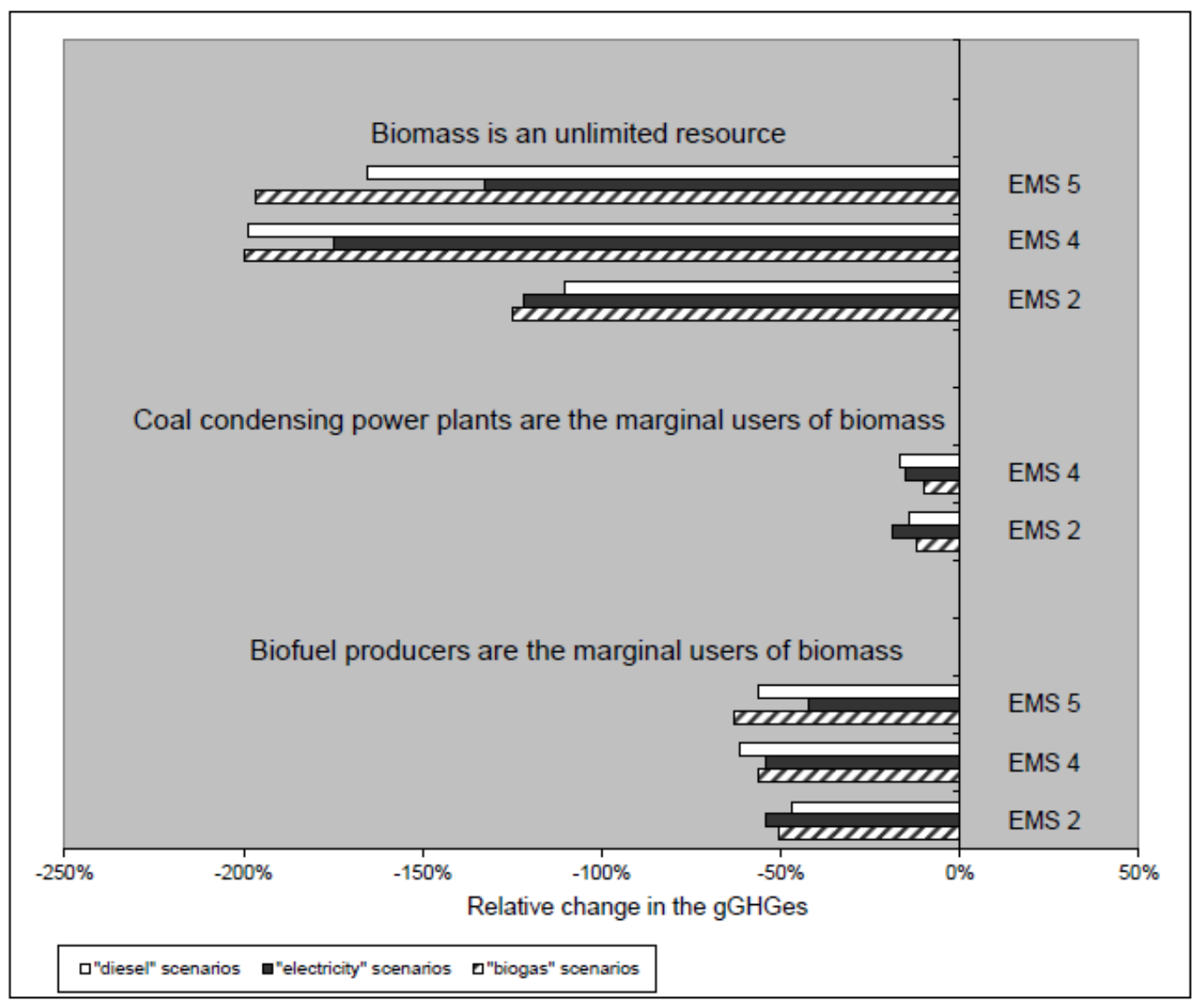

Figure 5 The changes in the gGHGes if $\mathrm{DH}$ producers were to invest in biofuel production rather than CHP production, and if CCS were performed in the new plants. 
Table 1. Technical and economic characteristics of the new waste-fired plants.

\begin{tabular}{cccc}
\hline & & $\begin{array}{c}\text { Waste-fuelled CHP } \\
\text { plant (Hansson et al., }\end{array}$ & $\begin{array}{c}\text { Waste-fuelled } \\
\text { biogas/CHP plant (E.ON, } \\
2011)\end{array}$ \\
\hline Waste input & $(\mathrm{MW})$ & 136 & 91 \\
Electricity efficiency & & 0.22 & 0.22 \\
Heat efficiency & 0.69 & 0.59 \\
Biogas efficiency & - & 0.12 \\
Operating and maintenance costs & $(€ / \mathrm{MWh})$ & 13.5 & 16 \\
per input & & \\
\hline
\end{tabular}

Table 2. Stockholm's TS in the year 2030 (the truck sector is not included in the study).

\begin{tabular}{|c|c|c|c|c|}
\hline & & $\begin{array}{l}\text { Passenger } \\
\text { cars }^{\mathrm{a}}\end{array}$ & $\begin{array}{c}\text { Taxi and } \\
\text { mobility service }\end{array}$ & Buses \\
\hline \multicolumn{2}{|c|}{ Number of vehicles (Byman, 2009) } & $1,026,840$ & $5,160^{b}$ & 5,123 \\
\hline $\begin{array}{c}\text { Average annual distance travelled } \\
\text { by vehicle (SIKA, 2011) }\end{array}$ & (km/year) & 12,500 & 30,000 & 57,000 \\
\hline Total annual distance & $\left(10^{6} \mathrm{~km} /\right.$ year $)$ & 12,836 & 155 & 292 \\
\hline
\end{tabular}

${ }^{a}$ Excluding taxi and mobility service.

${ }^{\mathrm{b}}$ Assumed as $0.5 \%$ of the number of passenger cars in the region.

Table 3. The future fuel economy $(\mathrm{kWh} / 100 \mathrm{~km})$, (Hjalmarsson et al., 2011; SIKA 2011).

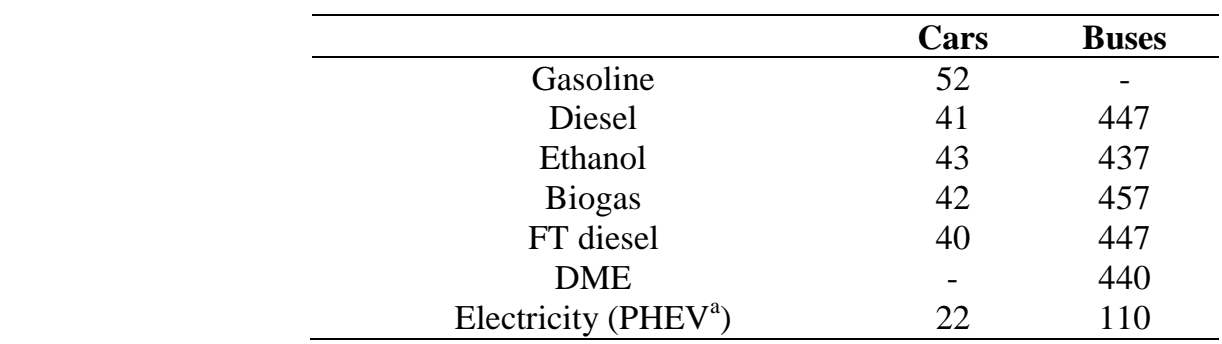

${ }^{a}$ Plug-in Hybrid Electric Vehicles 
Table 4. Economic and technical characteristics of the new plants (Hansson et al., 2007; Barta et al., 2010b; Wetterlund, 2010; Wetterlund et al., 2009).

\begin{tabular}{|c|c|c|c|c|c|c|}
\hline \multicolumn{2}{|c|}{ Type of the plant } & $\begin{array}{c}\text { Biomass } \\
\text { fuelled } \mathrm{CHP}^{\mathrm{a}}\end{array}$ & Ethanol/biogas & Ethanol & FT diesel & DME \\
\hline \multicolumn{7}{|c|}{ Efficiency } \\
\hline \multicolumn{2}{|c|}{ Electricity } & 0.34 & 0.05 & 0.12 & 0.06 & - \\
\hline \multicolumn{2}{|c|}{ Biofuel 1} & - & 0.34 & 0.34 & 0.45 & 0.62 \\
\hline \multirow{2}{*}{\multicolumn{2}{|c|}{$\begin{array}{c}\text { Biofuel } 2 \\
\text { Heat }\end{array}$}} & - & 0.25 & - & - & - \\
\hline & & 0.74 & 0.28 & 0.44 & 0.06 & 0.15 \\
\hline \multicolumn{7}{|c|}{ Economic characteristics } \\
\hline Base plant capacity & (MW) & 235 & $279^{\mathrm{b}}$ & $279^{b}$ & $300^{c}$ & $281^{\mathrm{d}}$ \\
\hline Base investment cost & $\left(€ \times 10^{6}\right)$ & - & 263 & 275 & 304 & 300 \\
\hline $\begin{array}{l}\text { Spec. investment cost } \\
\text { per input }\end{array}$ & $(€ / \mathrm{kW})$ & 757 & - & - & - & 1200 \\
\hline \multirow{2}{*}{$\begin{array}{c}\text { Fixed costs and } \\
\text { variable operating and } \\
\text { maintenance costs per } \\
\text { input }\end{array}$} & $\begin{array}{c}\text { (\% of the total } \\
\text { investment } \\
\text { cost) }\end{array}$ & 1.5 & 2.5 & 2.5 & 4.2 & 3.5 \\
\hline & $(€ / M W h)$ & 2.6 & - & - & - & 3.2 \\
\hline Operating time & (h/year) & 8000 & 8000 & 8000 & 8000 & 8000 \\
\hline \multicolumn{7}{|c|}{${ }^{\mathrm{a}}$ The efficiency of the biomass-fuelled CHP plant is increased by using fuel gas condensation. } \\
\hline
\end{tabular}


Table 5. EMSs for the year 2030. Carbon dioxide $\left(\mathrm{CO}_{2}\right)$ charge is included in the fossil fuel prices. (Axelsson et al., 2009; Axelsson and Harvey, 2010)

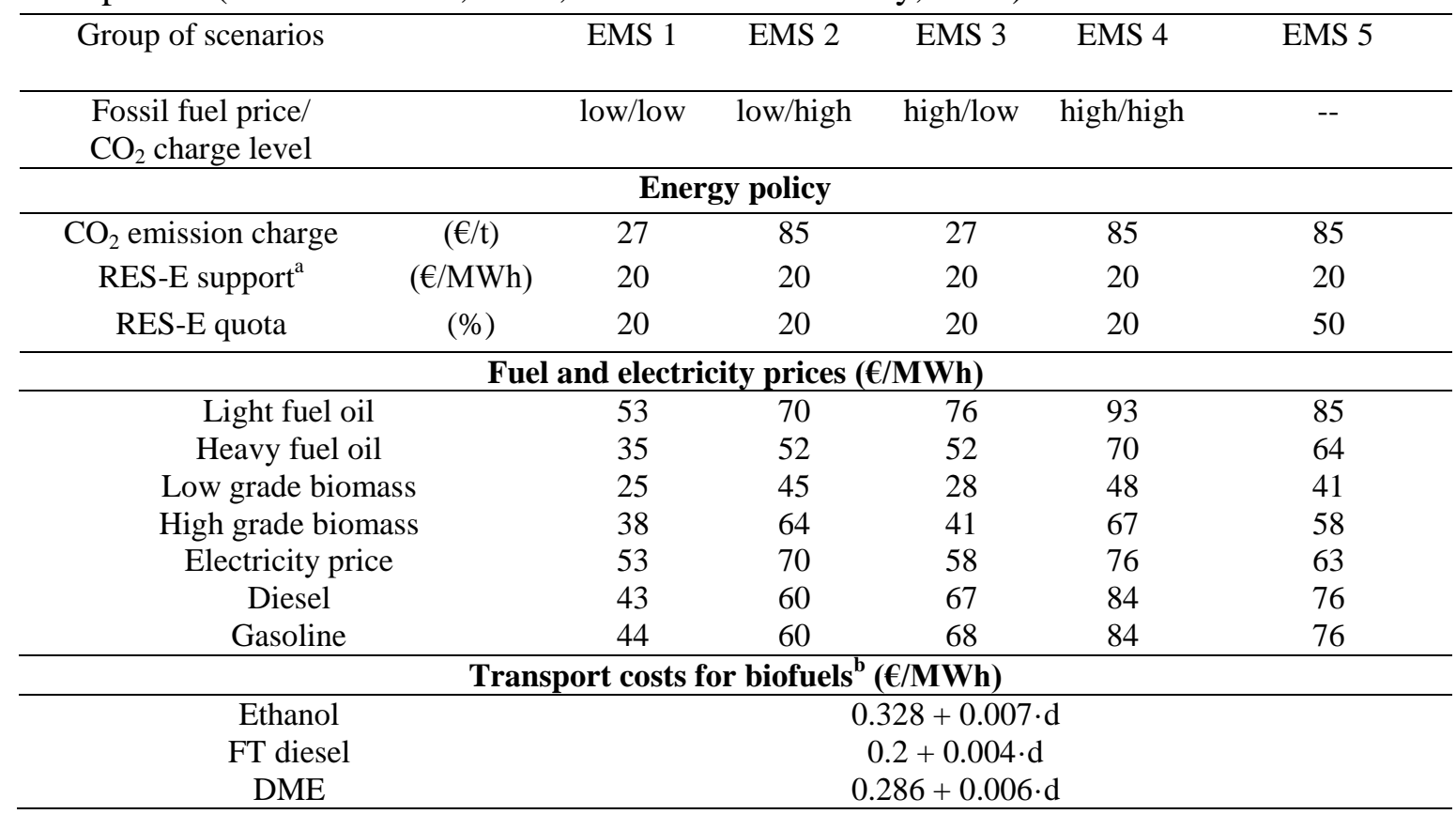

${ }^{a}$ Premium paid to producers of renewable electricity (above market electricity price).

${ }^{\mathrm{b}}$ (Wetterlund, 2010) The variable $\mathrm{d}$ is the distance from the plant to the filling station in $\mathrm{km}$. 
Table 6. Fossil GHG emissions factors $\left(\mathrm{kg} \mathrm{CO}_{2} \mathrm{eq} / \mathrm{MWh}\right)$ used in the study.

\begin{tabular}{|c|c|c|c|}
\hline & EMS $1 / 3$ & EMS 2/4 & EMS 5 \\
\hline \multicolumn{4}{|l|}{ Electricity sector } \\
\hline Build marginal electricity & Coal & 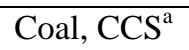 & $\mathrm{NGCC}^{\mathrm{a}}$ \\
\hline $\mathrm{CO}_{2} \mathrm{eq}$ emissions of the marginal electricity & 679 & 129 & 345 \\
\hline \multicolumn{4}{|c|}{ GHG emissions during the whole life cycle of the fossil fuels } \\
\hline Fuel oil & & 320 & \\
\hline Diesel, gasoline & & 299 & \\
\hline \multicolumn{4}{|c|}{ GHG emissions from waste combustion and transportation } \\
\hline Waste combustion & & 100 & \\
\hline Waste transportation & & 1.5 & \\
\hline \multicolumn{4}{|c|}{ Well-to-tank GHG emissions for biofuels } \\
\hline RME & & 95 & \\
\hline Biogas & & -70 & \\
\hline Ethanol & & 64 & \\
\hline \multicolumn{4}{|c|}{ GHG emissions from the biomass transportation and marginal effects of biomass used } \\
\hline Transportation in the reference scenarios & & 8.3 & \\
\hline $\begin{array}{c}\text { Transportation in the scenarios with large-scale } \\
\text { biofuel production }\end{array}$ & & 9.1 & \\
\hline Without marginal effects & & 0 & \\
\hline Coal power plants are the marginal users & 336 & 336 & - \\
\hline Producers of biofuel are the marginal users & 118 & 152 & 118 \\
\hline
\end{tabular}

\section{GHG emissions from transportation of biofuel}

$\begin{array}{cc}\text { Ethanol } & 0.2 \\ \text { FT diesel } & 0.3 \\ \text { DME } & 0.3\end{array}$

${ }^{\mathrm{a}}$ Coal, $\mathrm{CCS}=$ Coal power plant with CCS; NGCC $=$ Natural gas combined cycle plants.

Table 7. $\mathrm{CO}_{2}$ emission factors (kg/MWh) from total combustion (Edwards, 2011).

\begin{tabular}{cc}
\hline Fuel & $\mathrm{CO}_{2}$ emissions \\
\hline Biomass & 367 \\
Ethanol & 257 \\
Biogas & 198 \\
FT-diesel & 255 \\
DME & 242 \\
\hline
\end{tabular}

Table 8. The new plants introduced in the DHS.

\begin{tabular}{cccccc}
\hline Scenarios & r1-4 & r5 & b1-5 & e1-5 & d1-5 \\
\hline Type & \multicolumn{7}{c}{ Capacity $(\mathbf{M W})$} \\
\hline Ethanol/biogas & - & - & $3 \times 308$ & - & - \\
Ethanol & - & - & - & $4 \times 250$ & 304 \\
FT diesel & - & - & - & - & 302 \\
DME & - & - & - & - & 259 \\
CHP & $4 \times 220$ & $4 \times 220$ & $2 \times 250$ & 235 & $2 \times 300$ \\
\hline Total investment $\left(€ \times 10^{6}\right)$ & 670 & 670 & 1224 & 1197 & 1678 \\
\hline
\end{tabular}


Table 9. The $\mathrm{CO}_{2}$ capture potential per biomass input for the new plants.

\begin{tabular}{|c|c|}
\hline \multicolumn{2}{|c|}{ Captured $\mathrm{CO}_{2}(\mathrm{~kg} / \mathrm{MWh})$} \\
\hline Ethanol/biogas & 207 \\
\hline Ethanol & 252 \\
\hline FT diesel & 227 \\
\hline DME & 217 \\
\hline CHP & 330 \\
\hline
\end{tabular}

Table 10. The CCS potential and electricity required for the CCS process in different scenarios.

\begin{tabular}{ccccc}
\hline & Reference & "Biogas" & "Electricity" & "Diesel" \\
\hline \multicolumn{5}{c}{ Total $\mathrm{CO}_{2}$ captured $\left(\times 10^{6} \mathrm{t}\right)$} \\
\hline EMS 2 & 1.06 & 1.80 & 1.81 & 1.78 \\
EMS 4 & 1.58 & 2.16 & 2.03 & 2.34 \\
EMS 5 & 1.49 & 2.08 & 1.86 & 2.04 \\
\hline \multicolumn{5}{c}{ Electricity required $(\mathrm{GWh})$} \\
\hline EMS 2 & 148 & 252 & 253 & 249 \\
EMS 4 & 221 & 302 & 284 & 328 \\
EMS 5 & 209 & 291 & 260 & 286 \\
\hline
\end{tabular}

